\title{
Inhibition of glycogen synthase kinase $3 \beta$ suppresses coxsackievirus-induced cytopathic effect and apoptosis via stabilization of $\beta$-catenin
}

\author{
$\mathrm{J} \mathrm{Yuan}^{1,2}$, J Zhang ${ }^{1}$, BW Wong ${ }^{1}, \mathrm{X} \mathrm{Si}^{1}$, J Wong ${ }^{1}$, D Yang ${ }^{1}$ and \\ H Luo*,1,2 \\ ${ }^{1}$ Department of Pathology and Laboratory Medicine, The James Hogg \\ iCAPTURE Centre for Cardiovascular and Pulmonary Research, University of \\ British Columbia - St. Paul's Hospital, Vancouver, British Columbia, Canada \\ 2 These authors contributed equally to this work. \\ * Corresponding author: H Luo, The James Hogg iCAPTURE Center for \\ Cardiovascular and Pulmonary Research, University of British Columbia-St. \\ Paul's Hospital, 1081 Burrard St, Vancouver, BC, Canada V6Z 1 Y6. \\ Tel: + 604-682-2344ext. 62847; Fax: + 604-806-8351; \\ E-mail: hluo@mrl.ubc.ca
}

Received 14.12.04; revised 28.2.05; accepted 21.3.05; published online 20.5.05 Edited by G Nunez

\begin{abstract}
Coxsackievirus B3 (CVB3), a common human pathogen for viral myocarditis, induces a direct cytopathic effect (CPE) and apoptosis on infected cells. To elucidate the mechanisms that contribute to these processes, we studied the role of glycogen synthase kinase $3 \beta$ (GSK3 $\beta$ ). GSK3 $\beta$ activity was significantly increased after CVB3 infection and addition of tyrosine kinase inhibitors blocked CVB3-triggered GSK3 $\beta$ activation. Inhibition of caspase activity had no inhibitory effect on CVB3-induced CPE; however, blockage of GSK3 $\beta$ activation attenuated both CVB3-induced CPE and apoptosis. We further showed that CVB3 infection resulted in reduced $\beta$-catenin protein expression, and GSK3 $\beta$ inhibition led to the accumulation and nuclear translocation of $\beta$-catenin. Finally, we found that CVB3-induced CPE and apoptosis were significantly reduced in cells stably overexpressing $\beta$-catenin. Taken together, our results demonstrate that CVB3 infection stimulates GSK3 $\beta$ activity via a tyrosine kinasedependent mechanism, which contributes to CVB3-induced $\mathrm{CPE}$ and apoptosis through dysregulation of $\beta$-catenin.

Cell Death and Differentiation (2005) 12, 1097-1106.

doi:10.1038/sj.cdd.4401652; published online 20 May 2005
\end{abstract}

Keywords: coxsackievirus; apoptosis; cytopathic effect; GSK3 $\beta ; \beta$-catenin

Abbreviations: CVB3, coxsackievirus B3; GSK3 $\beta$, glycogen synthase kinase $3 \beta$; CPE, cytopathic effect; PI3K, phosphatidylinositol 3 kinase; PKB, protein kinase B; TCF/TEF, T-cell factor/ lymphocyte enhancer factor; $\mathrm{LiCl}$, lithium chloride; $\mathrm{MOI}$, multiplicity of infection; PFU, plaque-forming unit

\section{Introduction}

Coxsackievirus B3 (CVB3), a member of genus Enterovirus within the family of Picornaviridae, is the primary causative agent of viral myocarditis. ${ }^{1,2}$ In North America, viral myocarditis accounts for approximately $20 \%$ of sudden, unexpected death and heart failure in children and adolescents. ${ }^{3}$ In those patients that survive, human studies strongly suggest that the major chronic sequela is dilated cardiomyopathy, which is responsible for approximately $50 \%$ of the more than 57000 cardiac transplants now registered worldwide. ${ }^{4}$

Apoptosis plays an important role in the pathogenesis of a number of diseases, and has been shown to be associated with myocarditis and chronic dilated cardiomyopathy. Cumulative evidence suggests that both early direct virusmediated injury and subsequent inflammatory responses contribute to the injury of cardiac myocytes and the extent of such injury determines the severity of late stage organ dysfunction. ${ }^{2,7,8}$ In experimental animal models, CVB3 infection results in extensive apoptotic and necrotic phenotypic alterations of cardiomyocytes. ${ }^{9}$ In cultured cells, CVB3 infection is capable of inducing a direct cytopathic effect (CPE, a degenarative change in morphology) and cell apoptosis. ${ }^{10,11}$ We have recently demonstrated that the mitochondria-mediated apoptotic pathway that is involved in the early cell death and apoptosis during the late phase of virus infection facilitates viral progeny release. ${ }^{10,11}$ However, thus far, the precise mechanisms underlying development of the CPE and apoptosis remain to be elucidated.

Glycogen synthase kinase $3 \beta$ (GSK3 $\beta$ ), a serine/threonine protein kinase, was initially identified as an enzyme that inhibits glycogen synthesis through phosphorylation of glycogen synthase. Recent studies have revealed that GSK3 $\beta$ regulates a wide range of cellular functions, including development, gene expression, cytoskeletal organization, protein translation, cell cycle regulation, and apoptosis. ${ }^{12-14}$ In contrast to many protein kinases, GSK3 $\beta$ is catalytically active even in unstimulated cells and becomes inactivated by phosphorylation at serine 9. Conversely, dephosphorylation of this site or mutations that prevent phosphorylation, result in activation of the kinase. Several protein kinases including protein kinase $B$ (PKB, also knows as Akt), protein kinase $A$ and $C$, integrin-linked kinase, and $p 90^{\text {Rsk }}$ kinase, have been identified to negatively regulate GSK3 $\beta$ activity through serine phosphorylation. GSK3 $\beta$ is also inhibited by Wingless/Wnt signaling. However, phosphorylation of GSK3 $\beta$ at tyrosine 216 by tyrosine kinases can further increase its activity.

A number of GSK $3 \beta$ substrates has been identified, such as $\beta$-catenin, CREB, NFAT, cyclin D1, c-Myc, E-cadherin, and elF2B. ${ }^{12-14}$ Among them, $\beta$-catenin is one of the best characterized targets of GSK3 $\beta$. GSK3 $\beta$ phosphorylates $\beta$-catenin, targeting it for ubiquitination and degradation by proteasome ${ }^{13} \mathrm{At}$ the cell membrane, $\beta$-catenin links cadherins to the cytoskeleton, modulating cytoskeleton organization. $\beta$-catenin also functions as a transcriptional activator. Accumulation of $\beta$-catenin in the cytosol leads to its 
translocation to the nucleus, where it binds with T-cell factor (TCF)/lymphocyte enhancer factor (LEF) family members to induce expression of several survival genes. ${ }^{13}$

In this study, we explored the role of GSK3 $\beta$ in the regulation of CVB3-induced CPE and apoptosis in cultured cells. We demonstrate that CVB3 infection stimulates tyrosine kinase-dependent GSK3 $\beta$ activity, and inhibition of GSK3 $\beta$ activity prevents CVB3-induced CPE and apoptosis via stabilization of $\beta$-catenin.

\section{Results}

\section{CVB3 stimulates GSK3 $\beta$ activation}

To determine whether CVB3 infection can activate GSK3 $\beta$, we examined GSK3 $\beta$ kinase activity by an immune complex kinase assay at different time courses following CVB3 infection. There was a significant increase in GSK3 $\beta$ activity at $1 \mathrm{~h}$ postinfection (pi) and subsequent decrease at $4 \mathrm{~h}$ pi (Figure 1).

\section{Tyrosine kinase inhibitors block CVB3-induced GSK3 $\beta$ activation}

Previous studies have shown that Src family tyrosine kinases are activated early after CVB3 infection. ${ }^{15,16}$ To determine whether CVB3 infection activates tyrosine kinases, we examined tyrosine phosphorylation by Western blot analysis using antiphosphotyrosine monoclonal antibody. Consistent with previous reports, we demonstrated that CVB3 infection led to tyrosine phosphorylation as early as $10 \mathrm{~min}$ and peaked at 30 min following virus infection (Figure 2a). CVB3-induced tyrosine phosphorylation was dramatically reduced after addition of PP2 (a selective Src tyrosine kinase inhibitor). We further explored whether tyrosine kinases function as
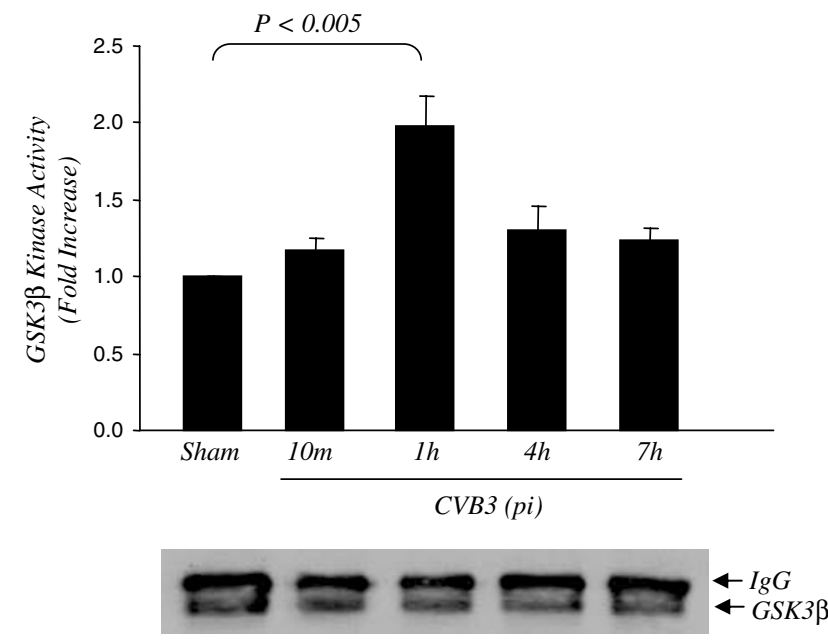

Figure 1 CVB3 infection stimulates GSK3 $\beta$ activation. Growth arrested HeLa cells were infected with CVB3. At $10 \mathrm{~min}, 1 \mathrm{~h}, 4 \mathrm{~h}$ and $7 \mathrm{~h}$ postinfection (pi), cell lysates were collected. GSK3 $\beta$ activity was determined by in vitro immune complex kinase assay (mean \pm S.E., $n=4$ ), and normalized to sham-infected cells, which was arbitrarily set to a value of 1.0. To verify equal amounts of precipitated GSK3 $\beta, 10 \mu \mathrm{l}$ reaction mixture was separated on an SDS-PAGE gel and Western blot was performed using anti-GSK3 $\beta$ antibody upstream activators triggering GSK3 $\beta$ activation following CVB3 infection by using two tyrosine kinase inhibitors PP2 and genistein (a general tyrosine kinase inhibitor). As shown in Figure $2 b$, treatment with PP2 or genistein significantly reduced CVB3-induced GSK3 $\beta$ activation at $1 \mathrm{~h}$ pi, suggesting that CVB3 regulates GSK3 $\beta$ activity through the activation of tyrosine kinases.

\section{GSK3 $\beta$ inhibitors block CVB3-induced CPE and apoptosis}

GSK3 $\beta$ has been implicated in the regulation of apoptosis in a variety of cell types. ${ }^{12-14}$ Overexpression of catalytically active GSK3 $\beta$ induced apoptosis in neuron cells and fibroblasts ${ }^{17}$ and contributes to human immunodeficiency virus type 1 Tat-mediated neurotoxicity. ${ }^{18}$ To examine whether inhibition of GSK3 $\beta$ activity protects cells against CVB3-induced CPE and apoptosis, we used two selective GSK3 $\beta$ inhibitors, $\mathrm{LiCl}$ and SB 415286. Inhibitor LiCl potently
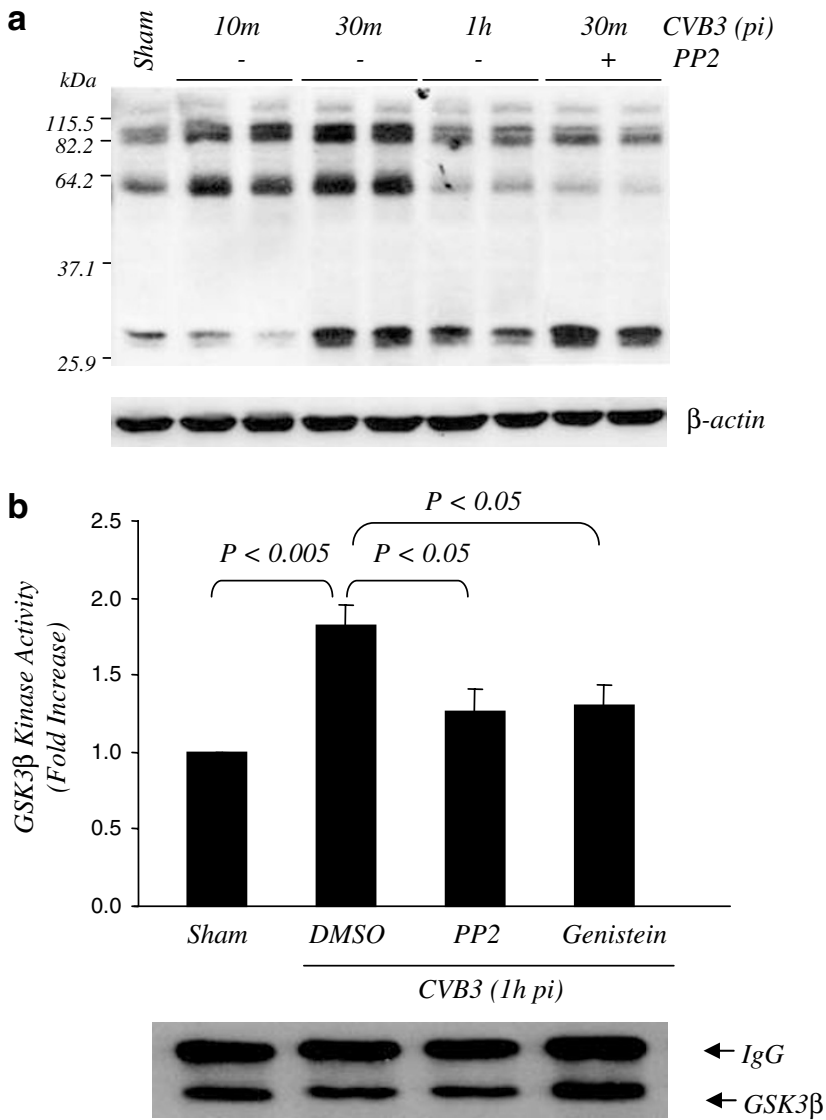

Figure 2 Tyrosine kinase inhibitors block CVB3-induced GSK3 $\beta$ activation. (a) Growth arrested HeLa cells, pretreated with or without Src tyrosine kinase inhibitor PP2 $(20 \mu \mathrm{M})$, were infected with CVB3 for the indicated time points. Tyrosine phosphorylation was determined by Western blot analysis using antiphosphotyrosine monoclonal antibody. These same samples were immunoblotted with an antibody to $\beta$-actin to illustrate equal protein loading. (b) Growth arrested HeLa cells were pretreated with vehicle or $20 \mu \mathrm{M} \mathrm{PP2}$ or $50 \mu \mathrm{M}$ genistein for $30 \mathrm{~min}$ and then infected with CVB3. At $1 \mathrm{~h}$ pi, cell lysates were collected and GSK3 $\beta$ activity was determined and normalized as described above (mean \pm S.E., $n=3$ ) 
inhibits GSK3 $\beta$ activity through competition for $\mathrm{Mg}^{2+19}$ while SB 415286 selectively inhibits GSK3 $\beta$ activity through a competitive inhibition of ATP binding site. ${ }^{20,21} \mathrm{HeLa}$ cells were pretreated with increasing doses of $\mathrm{LiCl}$ or SB 415286 for $30 \mathrm{~min}$ prior to CVB3 infection. At $16 \mathrm{~h}$ pi, cell viability was determined by MTS assay, which measures mitochondrial function. As shown in Figure 3a, both $\mathrm{LiCl}$ and SB 415286 prevented CVB3-induced cell death in a dose-dependent manner.

Caspase activation is an important event in CVB3-induced apoptosis, which leads to cleavage of downstream substrates and DNA fragmentation. ${ }^{10}$ Thus, we next examined the effect of GSK3 $\beta$ inhibition on CVB3-induced caspase-3 cleavage. We demonstrated that pretreatment with $\mathrm{LiCl}$ or SB 415286 dose-dependently inhibited CVB3-induced caspase-3 clea- vage (Figure $3 b$ ). We further found that the inhibitory effect was almost abolished when $\mathrm{LiCl}$ or SB 415286 was added $3 \mathrm{~h}$ after infection, when GSK3 $\beta$ levels returned to almost baseline (data not shown), supporting the notion that the inhibition of apoptosis by GSK3 $\beta$ inhibitors is dependent on the blockade of GSK3 $\beta$ activity.

We have previously demonstrated CPE and apoptosis following CVB3 infection of HeLa cells are two separate cellular responses to virus infection. Caspase activation and subsequent substrate cleavage are not responsible for coxsackievirus-induced cytopathic morphological changes, which include cell shrinking, rounding and eventually floating. ${ }^{10,11}$ Here, we further test whether inhibition of GSK3 $\beta$ activity prevents infected cells from morphological changes. As shown in Figure 3c, vehicle (DMSO)-treated cells exhibited

b
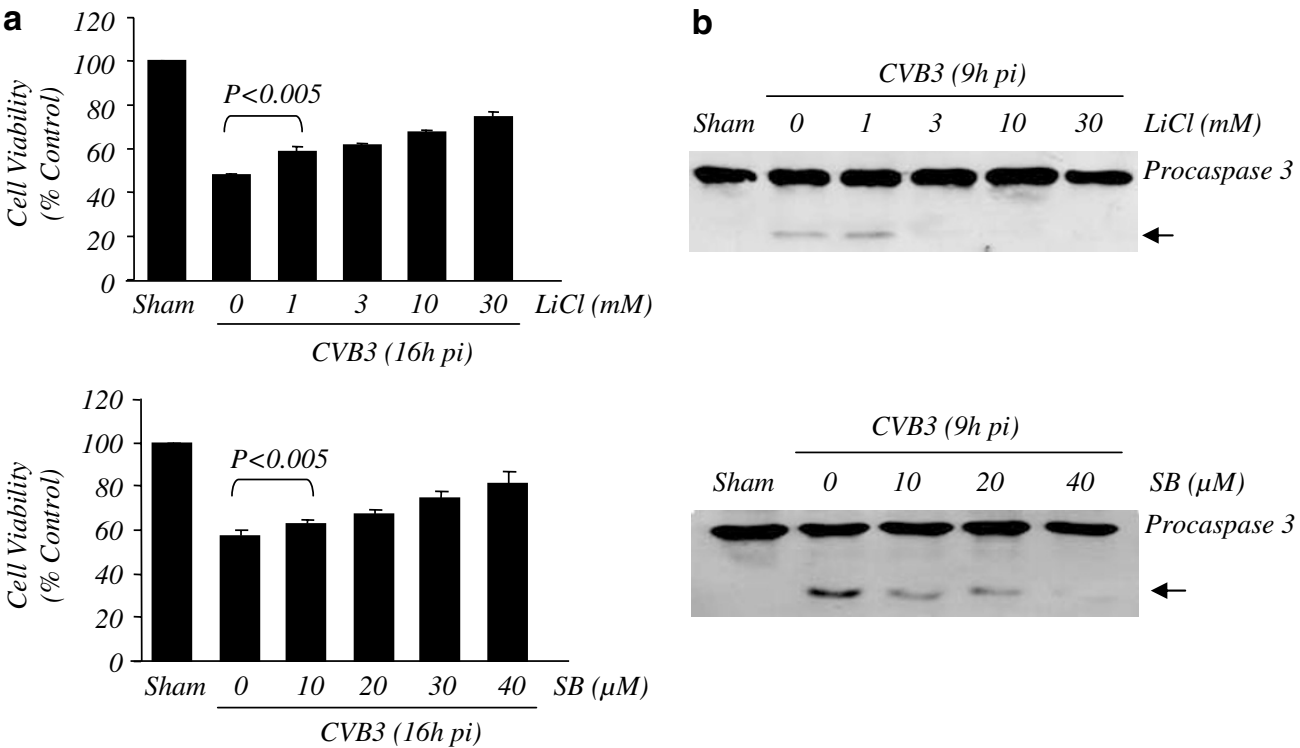

C
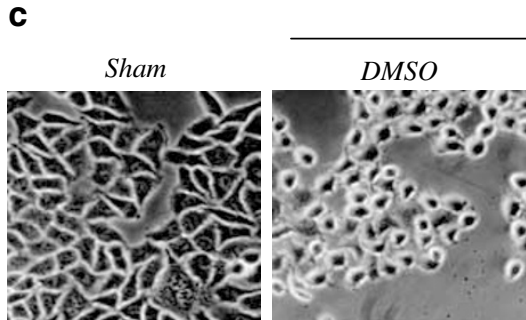

CVB3 (16h pi)

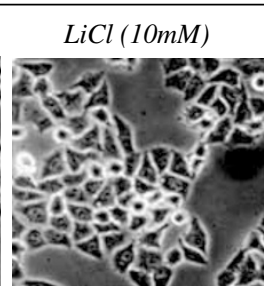

$z V A D(50 \mu M)$

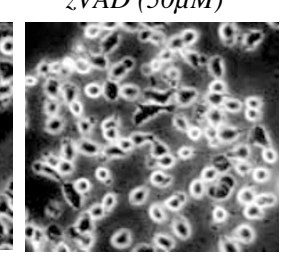

CVB3 $(16 h \mathrm{pi})$
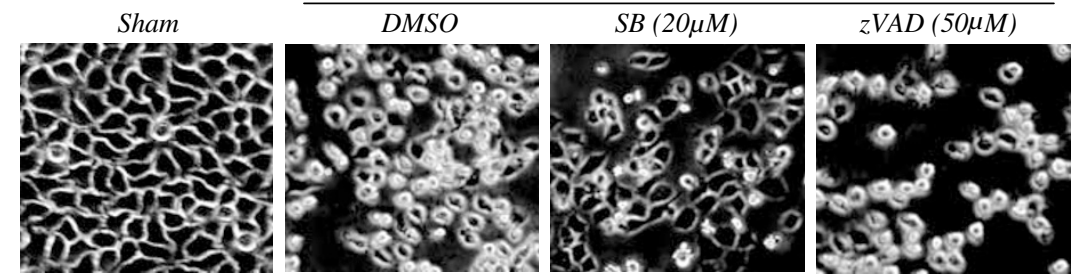

Figure 3 GSK3 $\beta$ inhibitors block CVB3-induced cytopathic effect and apoptosis. (a) HeLa cells were pretreated with vehicle or various concentrations of LiCl or SB 415286 for 30 min followed by infection with CVB3. Cell viability was determined at $16 \mathrm{~h}$ postinfection (pi) by the MTS assay that measures mitochondrial function (mean \pm S.E., $n=3$ ). In total, $100 \%$ survival was defined as the level of MTS in sham-infected cells in the absence of inhibitors. Similar results were obtained in three independent experiments. (b) HeLa cells were pretreated with LiCl or SB 415286 as described above. At $9 \mathrm{~h}$ pi, cell lysates were harvested and Western blotting was performed to examine the cleavage of caspase-3. Similar results were obtained in two independent experiments. (c) Representative phase contrast microscopy of HeLa cells treated with $10 \mathrm{mM} \mathrm{LiCl,} 20 \mu \mathrm{M}$ SB 415286 or $50 \mu \mathrm{M}$ zVAD.fmk at $16 \mathrm{~h}$ pi 
marked degenerative changes in morphology. Consistent with previous reports, ${ }^{10}$ blockage of caspase activity by a general caspase inhibitor zVAD.fmk had no inhibitory effect on virusinduced morphological changes, with the cells maintaining morphology similar to that of vehicle-treated, infected cells. However, pretreatment with $\mathrm{LiCl}$ or SB 415286 prevented cells from virus-induced morphological changes, suggesting that GSK3 $\beta$ might function as a converging enzyme regulating both CPE and apoptosis.

\section{Inhibition of GSK3 $\beta$ decreases viral progeny release but not viral protein expression}

To further explore whether the inhibitory effect of GSK3 $\beta$ inhibitors on CPE and apoptosis is directly regulated by the GSK3 $\beta$ pathway or whether it is secondary to inhibition of virus replication, we examined the impact of GSK3 $\beta$ inhibition on viral protein production. HeLa cells were incubated with varying concentrations of $\mathrm{LiCl}$ and $\mathrm{SB}$ 415286 for $30 \mathrm{~min}$, followed by CVB3 infection. At $9 \mathrm{~h} \mathrm{pi}$, cell lysates were harvested for viral protein detection by Western blot. As shown in Figure 4a, the expression of viral capsid protein VP1 was unaltered in either the presence or absence of GSK3 $\beta$ inhibitors, indicating that GSK3 $\beta$ appears to directly regulate CVB3-induced apoptosis and CPE.

Apoptosis or cell death has been suggested to be beneficial for coxsackievirus infection via facilitating viral progeny release and spread. ${ }^{10,11}$ We examined the role of GSK3 $\beta$ inhibitors in viral progeny release. As expected, addition of $\mathrm{LiCl}$ or SB 415286 led to reduced virus titers in the supernatant as assessed by plaque assay (Figure 4b), supporting an important role for apoptosis in virus lifecycle.

\section{CVB3 reduces $\beta$-catenin expression via a GSK3 $\beta$-dependent mechanism}

To further elucidate the mechanisms by which GSK3 $\beta$ regulates CVB3-induced CPE and apoptosis, we examined the downstream targets of GSK3 $\beta$. $\beta$-Catenin is one of the major targets of GSK3 $\beta$ and has been implicated to play a critical role in cell survival and cytoskeleton organization. ${ }^{13}$ GSK3 $\beta$ targets $\beta$-catenin for ubiquitination and degradation through the proteasome pathway. We first examined the expression of $\beta$-catenin following CVB3 infection. We found that CVB3 infection led to decreased expression of $\beta$-catenin at 5 and $7 \mathrm{~h}$ pi (Figure 5a). To further clarify whether CVB3 infection affects membrane and/or cytoplasmic levels of $\beta$-catenin, cell fractionation was carried out. We found that both membrane and cytoplasmic levels of $\beta$-catenin were reduced after viral infection (Figure $5 b$ ). We then determined whether CVB3-mediated downregulation of $\beta$-catenin is dependent on GSK3 $\beta$ activity. We examined the $\beta$-catenin expression in the SB 415286-treated cells following $5 \mathrm{~h}$ virus infection. As shown in Figure 6a, CVB3induced decreased expression of $\beta$-catenin was reversed after addition of SB 415286, which is consistent with our previous finding that $\mathrm{LiCl}$ induced an accumulation of $\beta$-catenin in infected HeLa cells, ${ }^{22}$ indicating that CVB3-
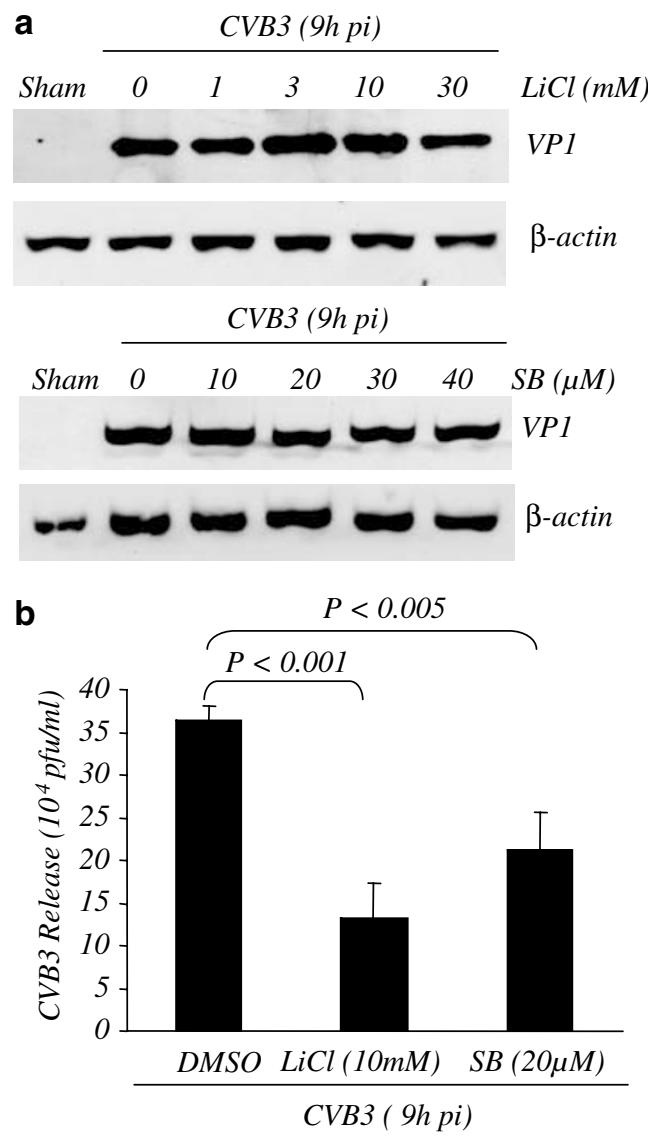

Figure 4 Effect of GSK3 $\beta$ inhibition on viral protein expression and viral progeny release. (a) HeLa cells were preincubated with different concentrations of GSK3 $\beta$ inhibitors, LiCl and SB 415286, for $30 \mathrm{~min}$ and then infected with CVB3. Cell lysates were collected $9 \mathrm{~h}$ postinfection and Western blot analysis was performed using a polyclonal antibody that recognizes CVB3 capsid protein VP1. $\beta$-Actin was probed as protein loading control. Data represent one of two different experiments. (b) HeLa cells were treated with $10 \mathrm{mM} \mathrm{LiCl}$ or $20 \mu \mathrm{M} \mathrm{SB}$ 415286 in an identical manner as described above. Medium was collected from CVB3 infected HeLa cells $9 \mathrm{~h}$ following infection and virus titers were determined by plaque assays on HeLa cell monolayers. Values are mean \pm S.E. from three independent experiments, where titrations were carried out in triplicate

mediated downregulation of $\beta$-catenin is dependent on GSK3 $\beta$ activation.

To further clarify how GSK3 $\beta$ inhibitors affect $\beta$-catenin expression and subsequently prevent virus-induced CPE and apoptosis, we performed immunocytochemical staining to detect the expression and localization of $\beta$-catenin. Immunofluorescent microscopy revealed that in unstimulated cells, $\beta$-catenin was localized to the plasma membrane and the cytosol (Figure 6b). Following CVB3 infection, cells appeared rounded up and $\beta$-catenin expression was decreased. Upon addition of $\mathrm{LiCl}$ and SB 415286, however, CVB3induced CPE was prevented, accompanied by an increased membrane localization and nuclear translocation of $\beta$-catenin. In comparison, inhibition of caspase activation using the general caspase inhibitor zVAD.fmk had no effect on either CVB3-induced cell morphological changes or $\beta$-catenin expression and localization (Figure 6b), indicating that GSK3 $\beta$-related morphological changes are independent of caspase activity. 
a


Figure 5 CVB3 infection reduces $\beta$-catenin expression. (a) HeLa cells were infected with CVB3. At 3, 5, and $7 \mathrm{~h}$ postinfection (pi), cell lysates were collected and analyzed for $\beta$-catenin expression by Western blot. $\beta$-Catenin expression was quantitated by densitometric analysis (mean \pm S.E., $n=4$ or 5 ) using National Institutes of Health ImageJ 1.27z, and normalized to sham-infected cells at each time point, which was arbitrarily set to a value of 1.0. (b) At $7 \mathrm{~h}$ pi, cell lysates were harvested and then fractionated into the cytoplasmic and membrane fractions as described in 'Material and Methods'. $\beta$-Catenin expression was quantitated by densitometric analysis, and normalized to the sham-infected cells, which was arbitrarily set to a value of 1.0

\section{Overexpression of $\beta$-catenin inhibits CVB3-induced CPE and apoptosis}

To further investigate the contribution of $\beta$-catenin as a key downstream effector of GSK3 $\beta$ to CVB3-induced CPE and apoptosis, we established stable cell lines overexpressing wild-type $\beta$-catenin or vector control (Figure 7a).

Cell lines containing the plasmid $\mathrm{pCIneo-} \beta$-catenin or vector alone were infected with CVB3. At 9 or $16 \mathrm{~h}$ pi, influence of $\beta$-catenin overexpression on CPE and apoptosis was determined morphologically, by cell viability assay and Western blot. As compared to vector alone control, overexpression of $\beta$-catenin resulted in a significant reduction of CVB3-mediated cell death as measured by cell viability assay (Figure $7 b$ ). Furthermore, immunoblotting for caspase-3 cleavage was performed to evaluate CVB3-induced apoptosis. We found that CVB3-induced caspase- 3 cleavage was inhibited in cells overexpressing $\beta$-catenin (Figure $7 \mathrm{c}$ ). As well, $\beta$-catenin overexpression alleviated degenerative morphology in CVB3-infected cells (Figure 7d). Taken together, the data obtained by overexpressing $\beta$-catenin in CVB3-infected cells are consistent with those obtained by inhibition of GSK3 $\beta$, indicating that $\beta$-catenin is a major downstream of GSK3 $\beta$ contributing to the regulation of CVB3-induced CPE and apoptosis.

\section{Overexpression of $\beta$-catenin inhibits viral progeny release but not viral protein expression}

We have demonstrated that inhibition of GSK3 $\beta$ decreases viral progeny release. To further elucidate whether the contribution of GSK3 $\beta$ to viral progeny release is via $\beta$-catenin, viral protein VP1 and virus titer were measured by Western blot and plaque assay at $9 \mathrm{~h}$ pi, respectively. Similar to the results obtained by inhibiting GSK3 $\beta$ activity using $\mathrm{LiCl}$ or SB 415286 (Figure 4), overexpression of $\beta$ catenin inhibited viral progeny release but not viral protein synthesis (Figure $8 a, b$ ), suggesting that regulatory effect of GSK3 $\beta$ on virus release may be through the regulation of its downstream target $\beta$-catenin.

\section{Discussion}

In the present study, we have shown that CVB3 infection stimulates GSK3 $\beta$ activity via an upstream signaling pathway depending on the activation of tyrosine kinases. Inhibition of GSK3 $\beta$ activity prevents CVB3-induced CPE and apoptosis. We have further shown that CVB3 infection reduces the expression of $\beta$-catenin through a GSK3 $\beta$-dependent mechanism. $\beta$-Catenin overexpression alleviates CVB3-induced 


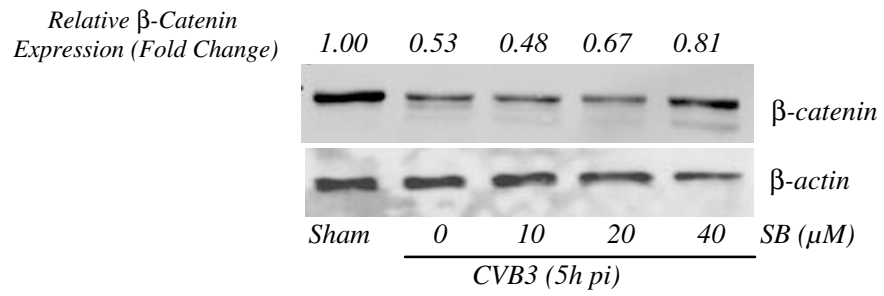

b Sham $C V B 3$ $C V B 3+\operatorname{LiCl}(30 m M) \quad C V B 3+S B(40 \mu M)$ $C V B 3+z V A D(50 \mu M)$
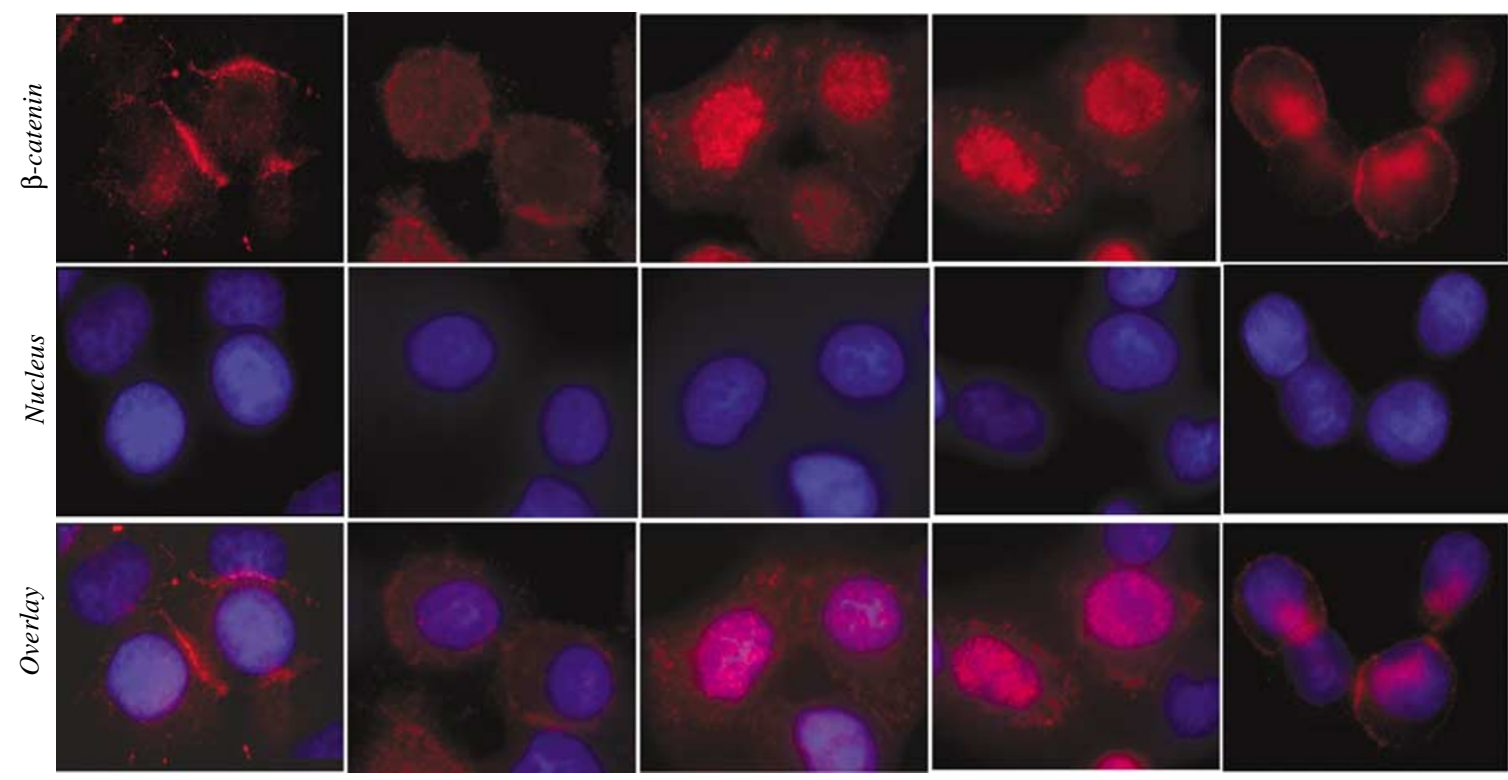

Figure 6 GSK3 $\beta$ inhibition leads to accumulation and nuclear translocation of $\beta$-catenin. (a) HeLa cells were preincubated with different concentrations of GSK3 $\beta$ inhibitor SB 415286, and then infected with CVB3. At $5 \mathrm{~h}$ after CVB3 infection, cell lysates were analyzed for $\beta$-catenin expression by Western blot. $\beta$-Catenin expression was quantitated by densitometric analysis, and normalized to the sham-infected cells, which was arbitrarily set to a value of 1.0. Data represent one of two different experiments. (b) HeLa cells were pretreated with $30 \mathrm{mM}$, LiCl, $40 \mu \mathrm{M} \mathrm{SB} 415286$, or $50 \mu \mathrm{M}$ zVAD.fmk for $30 \mathrm{~min}$, and then infected with CVB3. At $6 \mathrm{~h}$ postinfection, HeLa cells were fixed and immunocytochemically stained for $\beta$-catenin (red). Cell nuclei were counterstained with Hoechst 33342 (blue)

CPE and apoptosis, similar to the effects obtained by GSK3 $\beta$ inhibitor treatment. Additionally, inhibition of GSK3 $\beta$ activity or overexpression of $\beta$-catenin reduces viral progeny release, but has no effect on viral protein synthesis. Thus, our data demonstrate, for the first time, that GSK3 $\beta$ pathway plays a critical role in the regulation of CVB3-induced CPE and apoptosis. Together with previous report that GSK3 $\beta$ activation induced by HIV-1 Tat protein is responsible for virusmediated neurotoxicity, ${ }^{18}$ our finding in this study raises the possibility that GSK3 $\beta$ activation may represent a general strategy evolved by various cytopathic viruses to induce CPE and cell apoptosis although further experiment is necessary to test this hypothesis.

The activity of GSK3 $\beta$ is regulated by phosphorylation at both serine and tyrosine residues. Phosphorylation of GSK3 $\beta$ at Ser9 inhibits its enzymatic activity, whereas phosphorylation at Tyr216 can further increase its kinase activity. 23,24 Tyrosine kinases such as proline-rich tyrosine kinase, ${ }^{25} \mathrm{Src}$ family member Fyn tyrosine kinase, ${ }^{26}$ and zaphod tyrosine kinase $^{27}$ have been reported to activate GSK3 $\beta$ through tyrosine phosphorylation. In this study, we have shown that CVB3 infection stimulates GSK3 $\beta$ activity at $1 \mathrm{~h}$ pi via a tyrosine kinase-dependent mechanism. Although the exact tyrosine kinase(s) has not yet been identified, the Src tyrosine kinase family members, which were shown to be activated early after virus infection, ${ }^{15,16}$ are likely the upstream kinases responsible to GSK3 $\beta$ activation during CVB3 infection. At $4 \mathrm{~h}$ pi, GSK3 $\beta$ activity returns to basal levels. It is not clear whether such reduction is due to transient virus-receptor binding effect or due to negative regulation by upstream kinases. We have recently reported that $C V B 3$ induces phosphatidylinositol 3 kinase (PI3K)/PKB activation after $3 \mathrm{~h}$ of infection. ${ }^{28,29}$ Serine phosphorylation of GSK3 $\beta$ by PKB leads to a decreased GSK3 $\beta$ activity. Therefore, it is likely that downregulation of GSK3 $\beta$ activity at $4 \mathrm{~h}$ pi is caused by increased PKB phosphorylation. Indeed, we have shown that GSK3 $\beta$ serine phosphorylation occurs following CVB3 infection. ${ }^{28}$ Taken together, during the course of CVB3 infection, the $1 \mathrm{~h}$ peak of GSK3 $\beta$ activity and the $4 \mathrm{~h}$ return to baseline are likely to be rendered by different signaling pathways, reflecting the multiple virus and host mechanisms involved in virus infection and the crosstalk that exists between various pathways.

Studies by our laboratory and others have suggested that CPE and apoptosis triggered by CVB3 infection are two separate cellular responses. CPE is a typical feature of CVB3 infection, characterized by degenerative changes in cell 
a



b

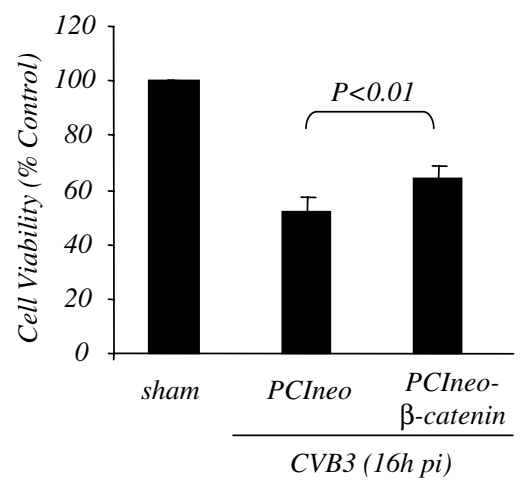

C



d

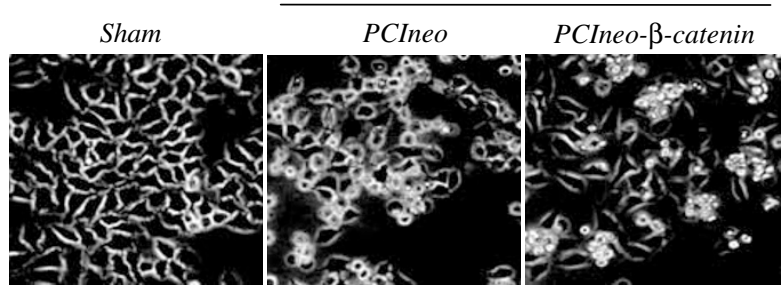

Figure 7 Overexpression of $\beta$-catenin inhibits CVB3-induced cytopathic effect and apoptosis. (a) Expression of $\beta$-catenin in $\beta$-catenin stable cells and vector control cells was determined by Western blot. The same blots were stripped and reprobed with anti- $\beta$-actin antibody to verify equal protein loading. (b) Stable HeLa cells were infected with CVB3. Cell viability was determined at $16 \mathrm{~h}$ postinfection (pi) by the MTS assay (mean \pm S.E., $n=3$ ). In total, $100 \%$ survival was defined as the level of MTS in sham-infected cells. (c) Stable cell lines were infected with CVB3 as described above. At $9 \mathrm{~h}$ pi, cell lysates were harvested and Western blotting was performed to examine the cleavage of caspase- 3 . (d) Representative phase contrast microscopy of HeLa cells overexpressing $\beta$-catenin or vector at $16 \mathrm{~h} \mathrm{pi}$

morphology, which includes cell shrinkage, cell rounding, and eventually cell detachment. Apoptosis is a distinct type of cell death following CVB3 infection, which is characterized by internucleosomal fragmentation of the genomic DNA. Cysteine protease caspases are the main executor enzymes of apoptotic process. In both CVB3 and poliovirus studies, it has been demonstrated that caspases are activated subsequent to degenerative morphological changes and that caspase inhibitors are able to inhibit apoptosis but not CPE, indicating that the pathways leading to the virus-induced CPE and apoptosis are separate. ${ }^{10,30}$ It has been suggested that viral


Figure 8 Effect of $\beta$-catenin overexpression on viral protein expression and viral progeny release. (a) Stable HeLa cells overexpressing $\beta$-catenin or vector were infected with CVB3. Cell lysates were collected $9 \mathrm{~h}$ postinfection and Western blot analysis was performed using a polyclonal antibody that recognizes capsid protein VP1. These same samples were immunoblotted with an antibody to $\beta$-actin to illustrate equal protein loading. (b) Stable cell lines were infected with CVB3 as described above. Medium was collected from CVB3 infected cells $9 \mathrm{~h}$ following infection and virus titers were determined by plaque assays. Values are mean \pm S.E. from three independent experiments, where titrations were carried out in triplicate

proteases induce cleavage of host proteins, which may be responsible for changes in cell shape. ${ }^{31}$ However, the mechanisms of CPE remain largely unknown. In this study, we have demonstrated that the GSK3 $\beta / \beta$-catenin pathway acts as a multifunctional regulator of both CVB3-induced CPE and apoptosis.

Coxsackievirus B3 utilizes host cellular machinery in many different ways to promote infectivity. Our laboratory has reported that several signaling pathways participate in the regulation of CVB3 replication. For example, CVB3 activates the extracellular signal-regulated kinase and $\mathrm{PI} / \mathrm{K} / \mathrm{PKB}$ signaling pathways during the course of infection to facilitate its own replication. ${ }^{28,32}$ If $\mathrm{PI} K \mathrm{~K}$ regulates viral replication through GSK3 $\beta$, inhibition of PI3K or overactivation of GSK3 $\beta$ should exert consistent effects on viral protein expression and progeny release since $\mathrm{PI} 3 \mathrm{~K}$ is a negative regulator to GSK3 $\beta$. However, we have shown that inhibition of GSK3 $\beta$ does not affect viral protein expression, but reduces virus release. This discrepancy could be due to the involvement of other downstream effector(s) of $\mathrm{PI} 3 \mathrm{~K} / \mathrm{PKB}$ in the regulation of CVB3 replication. We have previously shown that overexpression of $\mathrm{Bcl}-2$ or $\mathrm{Bcl}-\mathrm{xL}$, or treatment with caspase inhibitor zVAD.fmk decreases virus release, suggesting that host cell apoptosis facilitates the release of progeny virus from infected cells. ${ }^{11}$ Thus, the mechanism by which $\mathrm{LiCl}$ or SB 415286 inhibits virus release is likely an indirect result of their antiapoptotic effects in infected cells.

Many proteins have been reported to be substrates of GSK3 $\beta .^{33}$ Based on its known functions, $\beta$-catenin, a substrate of GSK3 $\beta$, is likely a candidate participating in the regulation of apoptosis and CPE during CVB3 infection. Two major functions of $\beta$-catenin have been well described: the membrane-tethered $\beta$-catenin links adherens junction protein cadherins to the actin cytoskeleton, promoting cell-cell adhesion; and the cytoplasmic $\beta$-catenin functions as a transcriptional activator participating in maintaining cell survival. ${ }^{34}$ Recent studies have suggested that cells adapt various mechanisms to regulate the levels and localization of $\beta$-catenin to assure its specific function at different 
conditions. $^{34}$ During the cell cycle, protein expression of cytosolic $\beta$-catenin fluctuates, increasing at $S$ phase, reaching maximum at late $\mathrm{G} 2 / \mathrm{M}$ phase, then rapidly reducing in the next $\mathrm{G} 1$ phase. ${ }^{35,36}$ Knockdown of $\beta$-catenin gene expression using RNA interference results in cell growth arrest and detachment, whereas stabilization of $\beta$-catenin suppresses cell apoptosis. ${ }^{37-43}$ In this study, we have shown that CVB3 infection decreases protein expression of $\beta$-catenin via a GSK3 $\beta$-dependent mechanism, and overexpression of $\beta$-catenin inhibits CVB3-induced apoptosis and CPE. These findings suggest $\beta$-catenin is a key downstream effector of GSK3 $\beta$ in the regulation of apoptosis and cell morphology. Although the precise mechanisms by which $\beta$-catenin regulates CVB3-induced apoptosis are still unclear, we speculate that over the course of CVB3 infection, the balance of $\beta$-catenin protein levels and subcellular localization is altered, which results in an early CPE (via loss of membrane $\beta$-catenin) and a late apoptosis (via inhibition of antiapoptotic $\beta$-catenin signaling through the nucleus) of infected cells. However, we cannot rule out the possibility that other downstream targets of GSK3 $\beta$, such as c-Myc, c-Jun, CREB, STAT, and NFAT, may also play a role in GSK3 $\beta$ activationinduced CPE and apoptosis during CVB3 infection.

Based on our findings in this study, a proposed model is summarized in Figure 9. CVB3 infection increases GSK3 $\beta$ activity through an upstream pathway depending on the activation of tyrosine kinases. Inhibition of GSK3 $\beta$ activity by $\mathrm{LiCl}$ or SB 415286 leads to stabilization and accumulation of $\beta$-catenin in the cytoplasm, which in turn results in an increased membrane localization and nuclear translocation of $\beta$-catenin. Membrane-associated $\beta$-catenin links cadherin to cytoskeleton organization, resisting morphological destruction by CVB3. Nuclear-localized $\beta$-catenin binds with TCF/ LEF family members to trigger the expression of genes responsible for maintaining cell survival.

In summary, our findings elucidate the essential role of GSK3 $\beta$ signaling in host cells response to CVB3 infection.

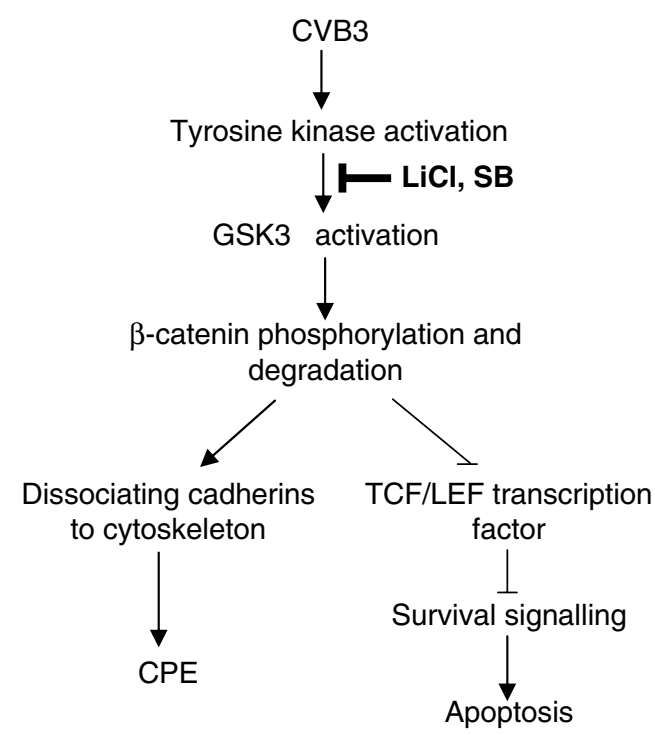

Figure 9 A proposed model for GSK3 $\beta$ regulation of CVB3-induced cytopathic effect and apoptosis (see text)
Considering the importance of CPE and apoptosis in viral infection, in host tissue damage, and in the progression to chronic diseases, modulating GSK3 $\beta$ activity or $\beta$-catenin expression may have important therapeutic implications.

\section{Materials and Methods}

\section{Cell culture and virus propagation}

HeLa cells were obtained from Charles Gauntt (University of Nebraska Medical Center, Nebraska, Omaha). They were cultured in Dulbecco's modified Eagle's medium (DMEM) supplemented with 10\% newborn calf serum and $100 \mu \mathrm{g} / \mathrm{ml}$ penicillin/streptomycin (Invitrogen Life Technologies) at $37^{\circ} \mathrm{C}$ in a humidified incubator with $5 \% \mathrm{CO}_{2}$. CVB3 (Nancy strain) was propagated in HeLa cells and stored at $-80^{\circ} \mathrm{C}$. Virus titers were routinely determined at the beginning of the experiment by plaque assay.

\section{Virus infection}

To minimize the influence of serum on the activation of signaling proteins, prior to virus infection, HeLa cells were serum starved by incubation in serum-free medium for $24 \mathrm{~h}$. Growth arrested HeLa cells were infected at a multiplicity of infection (MOI) of 10 with CVB3 or sham-infected with phosphate-buffered saline (PBS). After $1 \mathrm{~h}$ infection, cells were washed with PBS and replaced with fresh medium. For inhibition experiments, HeLa cells were pretreated with tyrosine kinase inhibitors PP2 (Calbiochem) or genistein (Calbiochem), or GSK3 $\beta$ inhibitors lithium chloride (LiCl; Sigma) or SB 415286 (GlaxoSmithKline), or general caspase inhibitor benzyloxycarbonyl-Val-Ala-Asp-fluoromethylketone (zVAD.fmk; Clontech) for $30 \mathrm{~min}$. Cells were then infected for $1 \mathrm{~h}$, washed with PBS, and placed in medium containing fresh inhibitors.

\section{Immune complex kinase assay}

GSK3 $\beta$ activity was determined by an immune complex kinase assay using glycogen synthase peptide-2 (Upstate Biotechnology) as a substrate as previously described. ${ }^{44}$ Briefly, $500 \mu \mathrm{g}$ of protein extracts from each sample were incubated with $1 \mu \mathrm{g}$ anti-GSK3 $\beta$ antibody (BD Biosciences Pharmingen) for $2 \mathrm{~h}$ and then immunoprecipitated with precleared protein G-Sepharose (Roche Applied Science) for $1 \mathrm{~h}$. Beads were washed and kinase activity was assayed in a total volume of $50 \mu \mathrm{l}$ reaction buffer containing $62.5 \mu \mathrm{M}$ glycogen synthase peptide-2, $20 \mathrm{mM}$ MOPS, $25 \mathrm{mM}$ $\beta$-glycerol phosphate (pH 7.2), $1 \mathrm{mM}$ EGTA, $1 \mathrm{mM}$ sodium orthovanadate, $1 \mathrm{mM}$ dithiothreitol, $15 \mathrm{mM} \mathrm{MgCl}_{2}, 20 \mu \mathrm{M}$ ATP and $1 \mu \mathrm{Ci} \gamma\left[{ }^{32} \mathrm{P}\right]$ ATP. After 20 min of incubation at $30^{\circ} \mathrm{C}$, reaction mixtures were centrifuged and $30 \mu \mathrm{l}$ of the supernatant was spotted onto P81 phosphocellulose papers (Whatman). Filters were washed in four changes of $0.75 \%$ phosphoric acid, rinsed in acetone, dried and then subjected to liquid scintillation counting. To verify equal amounts of precipitated GSK3 $\beta, 10 \mu$ l reaction mixture was separated on a sodium dodecyl sulfate-polyacrylamide gel electrophoresis (SDS-PAGE) and Western blot was performed using antiGSK3 $\beta$ antibody.

\section{Cell viability assay}

Cell viability (cell mitochondrial function) was measured by a 3-(4,5dimethylthiazol-2-yl)-5-(3-carboxymethoxyphenyl)-2-(4-sulfophenyl)-2Htetrazolium salt (MTS) assay (Promega), according to the manufacturers' instructions. Briefly, cells were incubated with MTS solution for $2 \mathrm{~h}$ and absorbance was measured at $492 \mathrm{~nm}$ using an enzyme-linked 
immunosorbent assay plate reader. The absorbance of sham-infected cells was defined as a value of $100 \%$ survival and the remaining data were converted to the ratio of the sham-infected sample. Morphological changes of cells following CVB3 infection were evaluated by phase contrast microscopy.

\section{Establishment of stable cell lines overexpressing $\beta$-catenin}

The $\mathrm{pCIneo-} \beta$-catenin construct expressing wild-type $\beta$-catenin was a generous gift from Drs. Bert Vogelstein and Kenneth W Kinzler (The Johns Hopkins University, Baltimore). HeLa cells at $60 \%$ confluence were transfected with $\mathrm{pCIneo-} \beta$-catenin or an empty vector (pClneo) using LipofectAMINE (Invitrogen Life Technologies), according to the manufacturers' instructions. At $48 \mathrm{~h} \mathrm{pi,} \mathrm{G418} \mathrm{(Sigma)} \mathrm{was} \mathrm{added} \mathrm{as} \mathrm{a} \mathrm{selective}$ marker at the final concentration of $400 \mu \mathrm{g} / \mathrm{ml}$ for selecting the transfected clones. Western blot was then performed to screen for $\beta$-catenin overexpression. Positive cell lines were maintained in complete DMEM with $100 \mu \mathrm{g} / \mathrm{ml}$ of $\mathrm{G} 418$. To further test whether $\beta$-catenin is functionally overexpressed in the stable cells, we examined TCF/LEF transcription activation by luciferase assay using luciferase reporter constructs containing wild type (pTOPFLASH, Upstate Biotechnology) or mutated (pFOPFLASH, Upstate Biotechnology) TCF/LEF binding site as previously described. ${ }^{45}$ We demonstrated that overexpression of $\beta$-catenin was sufficient to activate TCF/LEF transcription in HeLa cells (data not shown).

\section{Western blot analysis}

Western blot was performed by standard protocols as previously described. ${ }^{46}$ Equal amounts of protein were subjected to SDS-PAGE and then transferred onto nitrocellulose membranes. The membranes were blocked with $5 \%$ skim milk solution containing $0.1 \%$ Tween- 20 for $1 \mathrm{~h}$. The blots were then probed with primary antibody (monoclonal anti- $\beta$ catenin antibody (BD Transduction Laboratories); monoclonal antiphosphotyrosine antibody (PY20, Transduction Laboratories); monoclonal anti- $\beta$-actin antibody (Sigma); monoclonal antibody against viral protein VP1 (DAKO Co.); and polyclonal anti-caspase-3 antibody (Santa Cruz Biotechnology)) for $1 \mathrm{~h}$, followed by incubation with horseradish peroxidase-conjugated secondary antibody (Santa Cruz Biotechnology). Protein expression was detected by enhanced chemiluminescence (Amersham).

\section{Cell fractionation}

Cell fractionation was performed as previously described. ${ }^{47}$ Briefly, HeLa cells were washed with PBS, and then incubated in hypotonic lysis buffer (20 mM HEPES, pH 7.8, $10 \mathrm{mM} \mathrm{KCl}$ with phosphatase and protease inhibitors) for $15 \mathrm{~min}$ on ice. Cell lysates were harvested and then homogenized with 20 stokes in a Dounce homogenizer. After centrifugation at $250 \times g$ for $5 \mathrm{~min}$ to remove the nuclei and intact cells, the supernatant was collected and then further centrifuged at $100000 \times g$ for $1 \mathrm{~h}$ to separate the cytoplasm from the membrane fraction. Western blotting with an anti-DAF antibody was confirmed that there was no contamination of the cytoplasmic fractions with membrane fractions.

\section{Viral plaque assay}

The viral titer in the supernatant was determined by plaque assay as described previously. ${ }^{48}$ Cell supernatant was serially diluted and overlaid on monolayer of HeLa cells. Following $1 \mathrm{~h}$ of incubation, medium was removed and complete DMEM containing $0.75 \%$ agar was overlaid. After 3 days, cells were fixed with Carnoy's fixative for $30 \mathrm{~min}$ and then stained with $1 \%$ crystal violet. The plaques were counted and the viral titer (plaque-forming unit (PFU)/ml) was calculated.

\section{Immunocytochemical staining}

For visualization of $\beta$-catenin, cells were immunocytochemically stained using a monoclonal anti- $\beta$-catenin antibody. Briefly, following fixation in $10 \%$ formalin and permeabilization in $0.1 \%$ Triton X-100, cells were blocked with $10 \%$ normal goat serum for $1 \mathrm{~h}$, and then incubated with primary mouse anti- $\beta$-catenin antibody overnight. AlexaFluor ${ }^{\circledR}$ 594labeled goat anti-mouse IgG (Molecular Probes) was used to visualize primary antibody and Hoechst 33342 (Molecular Probes) was used to stain nuclei. Cells were imaged using a Nikon inverted microscope and Spot digital camera.

\section{Statistical analysis}

Two-way analysis of variance with multiple comparisons and paired Student's $t$-tests were performed. Data were shown as the mean \pm standard error (S.E.). $P<0.05$ was considered significant.

\section{Acknowledgements}

We thank Drs. Bert Vogelstein and Kenneth W Kinzler (The Johns Hopkins University, Baltimore) for providing the $\mathrm{pCIneo-} \beta$-catenin plasmid. This work was funded by grant from the Hospital for Sick Kids Foundation/ Canadian Institutes of Health Research (CIHR) (HL). JY and BWW are the recipients of a Doctoral Traineeship from the Heart and Stroke Foundation of Canada. BWW is the recipient of a CIHR Michael Smith Doctoral Research Award. XS is supported by a CIHR IMPACT Post-Doctoral Fellowship. $\mathrm{HL}$ is a New Investigator of the CIHR/St. Paul's Hospital Foundation Award and a Scholar of the Michael Smith Foundation for Health Research.

\section{References}

1. McManus BM, Chow LH, Radio SJ, Tracy SM, Beck MA, Chapman NM, Klingel $K$ and Kandolf $R$ (1991) Progress and challenges in the pathological diagnosis of myocarditis. Eur. Heart J. 12 (Suppl D): 18-21

2. Chow LH, Beisel KW and McManus BM (1992) Enteroviral infection of mice with severe combined immunodeficiency - evidence for direct viral pathogenesis of myocardial injury. Lab. Invest. 66: 24-31

3. Feldman AM and McNamara D (2000) Myocarditis. N. Engl. J. Med. 343: 13881398

4. Hosenpud JD, Bennett LE, Keck BM, Boucek MM and Novick RJ (2001) The Registry of the International Society for Heart and Lung Transplantation: Eighteenth Official Report-2001. J. Heart Lung Transplant. 20: 805-815

5. Bowles NE and Towbin JA (1998) Molecular aspects of myocarditis. Curr. Opin. Cardiol. 13: 179-184

6. Narula J, Kolodgie FD and Virmani R (2000) Apoptosis and cardiomyopathy. Curr. Opin. Cardiol. 15: 183-188

7. Mason JW, O'Connell JB, Herskowitz A, Rose NR, McManus BM, Billingham ME and Moon TE (1995) A clinical trial of immunosuppressive therapy for myocarditis - The Myocarditis Treatment Trial Investigators. N. Engl. J. Med. 333: $269-275$

8. McManus BM, Chow LH, Wilson JE, Anderson DR, Gulizia JM, Gauntt CJ, Klingel KE, Beisel KW and Kandolf R (1993) Direct myocardial injury by 
enterovirus: a central role in the evolution of murine myocarditis. Clin. Immunol. Immunopathol. 68: 159-169

9. Saraste A, Arola A, Vuorinen T, Kyto V, Kallajoki M, Pulkki K, Voipio-Pulkki LM and Hyypia T (2003) Cardiomyocyte apoptosis in experimental coxsackievirus B3 myocarditis. Cardiovasc. Pathol. 12: 255-262

10. Carthy CM, Granville DJ, Watson KA, Anderson DR, Wilson JE, Yang D, Hunt DW and McManus BM (1998) Caspase activation and specific cleavage of substrates after coxsackievirus B3-induced cytopathic effect in HeLa cells. J. Virol. 72: 7669-7675

11. Carthy CM, Yanagawa $B$, Luo $H$, Granville DJ, Yang D, Cheung $P$, Cheung $C$ Esfandiarei M, Rudin CM, Thompson CB, Hunt DW and McManus BM (2003) $\mathrm{Bcl}-2$ and $\mathrm{Bcl}-\mathrm{xL}$ overexpression inhibits cytochrome $\mathrm{c}$ release, activation of multiple caspases, and virus release following coxsackievirus B3 infection. Virology 313: 147-157

12. Doble BW and Woodgett JR (2003) GSK-3: tricks of the trade for a multi-tasking kinase. J. Cell Sci. 116 (Part 7): 1175-1186

13. Hardt SE and Sadoshima J (2002) Glycogen synthase kinase-3beta: a novel regulator of cardiac hypertrophy and development. Circ. Res. 90: 1055-1063

14. Harwood AJ (2001) Regulation of GSK-3: a cellular multiprocessor. Cell 105: 821-824

15. Liu P, Aitken K, Kong YY, Opavsky MA, Martino T, Dawood F, Wen WH, Kozieradzki I, Bachmaier K, Straus D, Mak TW and Penninger JM (2000) The tyrosine kinase p56lck is essential in coxsackievirus B3-mediated heart disease. Nat. Med. 6: 429-434

16. Opavsky MA, Martino T, Rabinovitch M, Penninger J, Richardson C, Petric M, Trinidad C, Butcher L, Chan J and Liu PP (2002) Enhanced ERK-1/2 activation in mice susceptible to coxsackievirus-induced myocarditis. J. Clin. Invest. 109: 1561-1569

17. Pap M and Cooper GM (1998) Role of glycogen synthase kinase-3 in the phosphatidylinositol 3-Kinase/Akt cell survival pathway. J. Biol. Chem. 273: 19929-19932

18. Maggirwar SB, Tong N, Ramirez S, Gelbard HA and Dewhurst S (1999) HIV-1 Tat-mediated activation of glycogen synthase kinase-3beta contributes to Tatmediated neurotoxicity. J. Neurochem. 73: 578-586

19. Ryves WJ and Harwood AJ (2001) Lithium inhibits glycogen synthase kinase-3 by competition for magnesium. Biochem. Biophys. Res. Commun. 280: 720-725

20. Cross DA, Culbert AA, Chalmers KA, Facci L, Skaper SD and Reith AD (2001) Selective small-molecule inhibitors of glycogen synthase kinase-3 activity protect primary neurones from death. J. Neurochem. 77: 94-102

21. Smith DG, Buffet M, Fenwick AE, Haigh D, Ife RJ, Saunders M, Slingsby BP, Stacey R and Ward RW (2001) 3-Anilino-4-arylmaleimides: potent and selective inhibitors of glycogen synthase kinase-3 (GSK-3). Bioorg. Med. Chem. Lett. 11: 635-639

22. Luo H, Zhang J, Dastvan F, Yanagawa B, Reidy MA, Zhang HM, Yang D, Wilson JE and McManus BM (2003) Ubiquitin-dependent proteolysis of cyclin D1 is associated with coxsackievirus-induced cell growth arrest. J. Virol. 77: $1-9$

23. Hughes K, Nikolakaki E, Plyte SE, Totty NF and Woodgett JR (1993) Modulation of the glycogen synthase kinase-3 family by tyrosine phosphorylation. EMBO J. 12: 803-808

24. Wang QM, Fiol CJ, DePaoli-Roach AA and Roach PJ (1994) Glycogen synthase kinase- 3 beta is a dual specificity kinase differentially regulated by tyrosine and serine/threonine phosphorylation. J. Biol. Chem. 269: 14566-14574

25. Hartigan JA, Xiong WC and Johnson GV (2001) Glycogen synthase kinase 3beta is tyrosine phosphorylated by PYK2. Biochem. Biophys. Res. Commun. 284: 485-489

26. Lesort M, Jope RS and Johnson GV (1999) Insulin transiently increases tau phosphorylation: involvement of glycogen synthase kinase-3beta and Fyn tyrosine kinase. J. Neurochem. 72: 576-584

27. Kim L, Liu J and Kimmel AR (1999) The novel tyrosine kinase ZAK1 activates GSK3 to direct cell fate specification. Cell 99: 399-408

28. Esfandiarei M, Luo H, Yanagawa B, Suarez A, Dabiri D, Zhang J and McManus BM (2004) Protein kinase B/Akt regulates coxsackievirus B3 replication through a mechanism which is not caspase dependent. J. Virol. 78: 4289-4298

29. Zhang HM, Yuan J, Cheung P, Luo H, Yanagawa B, Chau D, Stephan-Tozy N, Wong BW, Zhang J, Wilson JE, McManus BM and Yang D (2003)
Overexpression of interferon-gamma-inducible GTPase inhibits coxsackievirus B3-induced apoptosis through the activation of the phosphatidylinositol 3-kinase/Akt pathway and inhibition of viral replication. J. Biol. Chem. 278: 33011-33019

30. Agol VI, Belov GA, Bienz K, Egger D, Kolesnikova MS, Raikhlin NT, Romanova LI, Smirnova EA and Tolskaya EA (1998) Two types of death of poliovirusinfected cells: caspase involvement in the apoptosis but not cytopathic effect. Virology. 252: 343-353

31. Lyles DS (2000) Cytopathogenesis and inhibition of host gene expression by RNA viruses. Microbiol. Mol. Biol. Rev. 64: 709-724

32. Luo H, Yanagawa B, Zhang J, Luo Z, Zhang M, Esfandiarei M, Carthy C, Wilson JE, Yang D and McManus BM (2002) Coxsackievirus B3 replication is reduced by inhibition of the extracellular signal-regulated kinase (ERK) signaling pathway. J. Virol. 76: 3365-3373

33. Frame $S$ and Cohen $P$ (2001) GSK3 takes centre stage more than 20 years after its discovery. Biochem. J. 359 (Part 1): 1-16

34. Ben-Ze'ev A, Shtutman M and Zhurinsky J (2000) The integration of cell adhesion with gene expression: the role of beta-catenin. Exp. Cell Res. 261: 75-82

35. Olmeda D, Castel S, Vilaro S and Cano A (2003) Beta-catenin regulation during the cell cycle: implications in G2/M and apoptosis. Mol. Biol. Cell 14: 2844-2860

36. Orford K, Orford CC and Byers SW (1999) Exogenous expression of betacatenin regulates contact inhibition, anchorage-independent growth, anoikis, and radiation-induced cell cycle arrest. J. Cell Biol. 146: 855-868

37. Hurlstone $A$ and Clevers $\mathrm{H}$ (2002) T-cell factors: turn-ons and turn-offs. EMBO J. 21: 2303-2311

38. Cong F, Zhang J, Pao W, Zhou P and Varmus H (2003) A protein knockdown strategy to study the function of beta-catenin in tumorigenesis. BMC Mol. Biol. 4: 10

39. Verma UN, Surabhi RM, Schmaltieg A, Becerra C and Gaynor RB (2003) Small interfering RNAs directed against beta-catenin inhibit the in vitro and in vivo growth of colon cancer cells. Clin. Cancer Res. 9: 1291-1300

40. Chen S, Guttridge DC, You Z, Zhang Z, Fribley A, Mayo MW, Kitajewski J and Wang CY (2001) Wnt-1 signaling inhibits apoptosis by activating beta-catenin/T cell factor-mediated transcription. J. Cell Biol. 152: 87-96

41. Monga SP, Monga HK, Tan X, Mule K, Pediaditakis P and Michalopoulos GK (2003) Beta-catenin antisense studies in embryonic liver cultures: role in proliferation, apoptosis, and lineage specification. Gastroenterology 124: 202216

42. Shang XZ, Zhu H, Lin K, Tu Z, Chen J, Nelson DR and Liu C (2004) Stabilized beta-catenin promotes hepatocyte proliferation and inhibits TNFalpha-induced apoptosis. Lab. Invest. 84: 332-341

43. Satoh S, Daigo Y, Furukawa $Y$, Kato T, Miwa N, Nishiwaki T, Kawasoe T, Ishiguro H, Fujita M, Tokino T, Sasaki Y, Imaoka S, Murata M, Shimano T, Yamaoka $Y$ and Nakamura $Y$ (2000) AXIN1 mutations in hepatocellular carcinomas, and growth suppression in cancer cells by virus-mediated transfer of AXIN1. Nat. Genet. 24: 245-250

44. Tong H, Imahashi K, Steenbergen $C$ and Murphy $E$ (2002) Phosphorylation of glycogen synthase kinase-3beta during preconditioning through a phosphatidylinositol-3-kinase-dependent pathway is cardioprotective. Circ. Res. 90: 377-379

45. Skurk C, Maatz H, Rocnik E, Bialik A, Force T and Walsh K (2005) Glycogensynthase kinase3beta/beta-catenin axis promotes angiogenesis through activation of vascular endothelial growth factor signaling in endothelial cells. Circ. Res. 96: 308-318

46. Wang A, Cheung PK, Zhang $\mathrm{H}$, Carthy CM, Bohunek L, Wilson JE, McManus BM and Yang D (2001) Specific inhibition of coxsackievirus B3 translation and replication by phosphorothioate antisense oligodeoxynucleotides. Antimicrobial Agents Chemother. 45: 1043-1052

47. Krebs JF, Armstrong RC, Srinivasan A, Aja T, Wong AM, Aboy A, Sayers R, Pham B, Vu T, Hoang K, Karanewsky DS, Leist C, Schmitz A, Wu JC, Tomaselli KJ and Fritz LC (1999) Activation of membrane-associated procaspase-3 is regulated by Bcl-2. J. Cell Biol. 144: 915-926

48. Yuan J, Cheung PK, Zhang H, Chau D, Yanagawa B, Cheung C, Luo H, Wang Y, Suarez A, McManus BM and Yang D (2004) A phosphorothioate antisense oligodeoxynucleotide specifically inhibits coxsackievirus B3 replication in cardiomyocytes and mouse hearts. Lab. Invest. 84: 703-714 